\title{
A félreértések fogalmi alapú megközelítése és az intuíció, az introspekció helye a vizsgálatukban
}

A jelen tanulmány egy olyan kognitív szemantikai kutatás része, amely a nyelvi tevékenységekben tetten érhető félreértések vizsgálatát célozza a magyar nyelvben. A félreértések jelenségének a megértése az arisztotelészi logikai hagyományban gyökerezik, és ennek alapján a téves következtetésekhez sorolta az irodalom. Egyetértés mutatkozik ugyanakkor a jelenlegi ismeretek alapján abban, hogy a téves következtetések kialakulásában szemantikai és pragmatikai tényezőknek is szerepük van. Ebben az elméleti megközelítésben viszont még nem merült fel annak igénye, hogy megkülönböztesse a félreértés jelenségét a félrevezetéstől és a félremagyarázástól, valamint, hogy elhatárolja a fogalmi alapú félreértéseket a tisztán logikai természetü hibáktól. A tanulmány ezen szempontok alapján írja le a bevezetö részében a félreértés jelenséget kognitív szemantikai keretben, ismerteti az elméleti háttérfeltevéseket, ezt követően egy olyan esettanulmányt mutat be, amelyben a félreértés kialakulásában és tisztázásában a nyelvi intuíció és az introspekció szerepét valószínüsíti.

\section{Bevezető - a félreértés jelensége a kognitív nyelvészet elméleti keretében}

A nyelvhasználat adaptív emberi tevékenység, a kommunikációs igények kielégítésére, vagyis a megértésre (alkalmazkodás) és a megértetésre (alakítás) irányul (vö. Verschueren 1999: 61-5). A nyelvi tevékenység folyamatos választások sorozata is egyben (vö. Verschueren 1999: 116-20), amelyben a tudatosság mértéke különböző, és jelenti a megnyilatkozói stratégia (nyelvi forma) és a befogadói stratégia (elvárások) megválasztását. Ezek a választások nem egyenértékủek, egyrészt adott nyelvi formák választása felidézheti alternatíváit, másrészt a nem elvárt választások egyezkedést válthatnak ki arról, hogy milyen nyelvi megoldás fogadható el a felek számára, továbbá félreértéshez vezethetnek. Az elvárások a megnyilatkozói és a befogadói oldalról is természetes velejárói a kommunikációs tevékenységnek, elvárásainkat tapasztalataink, az adott körülmények és a mindenkori nyelvi normák (lásd Tolcsvai Nagy 1998: 31) alapján alakítjuk ki, és a másik félhez való kapcsolódást segítik. Adott beszédhelyzetben ugyanis nem pusztán egy információcsomagot értelmez a befogadó, hanem a megnyilatkozó sajátos valóságértelmezését, vagyis egy előzetesen már értelmezett és sajátosan elrendezett információhalmazt. Ebböl a befogadói attitüdből fogalmazható meg a kérdés, hogy milyen céllal és szándékkal ${ }^{1}$ címezte a megnyilatkozó az információt az adott befogadónak, és miért abban a nyelvi formában tette, ahogyan az megvalósult.

1 A kommunikációs és a nem kommunikációs jelenségek elhatárolásáról a szándéktulajdonítás alapján megoszlanak a vélemények az irodalomban (vö. Terestyéni 2014: 85-103). A jelen dolgozat nem foglal állást ebben a témában, mivel nyelvi interakcióban vizsgálja a félreértés jelenséget, és nem foglalkozik ettől eltérö helyzetekben megvalósuló félreértések elemzésével. 
A megértés-megértetés-félreértés viszonyában fontos megállapításokat tesz a szociálpszichológia a szociális kogníció fogalom kapcsán, miszerint az emberi kommunikációnak velejárója, hogy az eseményekhez, történésekhez attribúciós müveletekben okozati következtetéseket társít, mintegy megmagyarázva azok sikerét vagy kudarcát. Ennek célja többek között a kudarc elkerülése, a sikertelen viselkedési módok elvetése. A közösség tagja mások és a saját viselkedését is valamilyen típusba sorolja, és a kategorizáció müvelete adott cselekvés kimenetét tervezhetővé (elvárhatóvá és megítélhetővé) teszi a közösség tagjai számára. Ezek az értékelő műveletek konstruktívak és értelmező jellegủek, tehát befolyásolják az alkalmi jelentést, így az eltérhet a cselekvés várható sémájától (mintától) (lásd Fiske-Taylor 1991: 91-3). A minták begyakorlottsági foka hozzájárulhat az egyénileg eltérő nyelvi cselekvés és nyelvi forma létrehozásához, valamint annak megértéséhez. Ezen értékelő műveletekhez sorolhatók a másoknak tulajdonított vélt vagy valós szándékok mint mögöttes okok feltárása. ${ }^{2}$ Ugyanakkor egy megnyilatkozás értelmezése nem annak rekonstrukciója, hogy mire gondolhatott a megnyilatkozó, az értelmezés folyamata a megnyilatkozó intenciójának és a befogadó értelmezésének a sajátos interakciójaként írható le. Egy írott szöveg is időszerüen megtörténik a befogadóval, miközben a szövegböl szerzett ismereteket a mentális műveletek által reprezentálja a mentális világában (lásd a nyelvi tevékenységet mint interszubjektív megismerés és interperszonális kapcsolatteremtés egységét, Tomasello 2002; Tátrai 2017: 901-26). Mivel a nyelvi kifejezések jelentésük révén a világ valamely részét reprezentálják, szimbolizálják (kommunikációs szimbólumként funkcionálnak), a megnyilatkozó a gondolatait szükségszerüen süríti a nyelvi reprezentációkban, ennek következtében a befogadó többlettartalmakat ad a megnyilatkozáshoz az értelmezés során, amelyben támaszkodik a korábbi ismereteire, a tapasztalataira. Föltehetö, hogy a félreértések vizsgálatában a befogadó részéröl alkotott többlettartalmak között, a megnyilatkozónak tulajdonított szándék(ok) lényeges(ek) a kölcsönös megértés szempontjából - a jelen tanulmány ezzel foglalkozik -, ami a kognitív (ön)ellenörzés különböző formáin keresztül (pl. visszakérdezés, kikövetkeztetés a válaszból, a nonverbális jelekből, a szupraszegmentális szerkezetből stb.) többnyire nyomon követhető nemcsak a kommunikációban résztvevő felek, hanem a nyelvhasználat vizsgálatát célzó kutatók számára is. A kommunikációs felek reprezentációja a saját tudatos szándékukról, valamint a tudattalan szándékaik kikerülnek a félreértések jelen vizsgálatának a fókuszából.

A megnyilatkozónak tulajdonított szándék nézöpontjából tisztázható a különbség a félrevezetés mint viselkedési forma, a félremagyarázás, illetve a félreértés jelensége között, az utóbbinál ugyanis nem tételeződik fel a tudatos szándék, míg az előzőeknél igen. Habermas nyomán a kommunikációs cselekvést megkülönböztetem a stratégiai cselekvéstől, az utóbbi a másik személyt ellenlábasként (nem pedig egyenrangú félként) kezeli, és annak befolyásolására (nem pedig érvek segítségével történő meg-

2 Lásd pragmatikai keretben: számos stílusjegy (beszédtempó, hangerő, hanglejtés, szóhasználat) határozza meg a nyelvi viselkedésmódunkat, de ,nem vesszük észre őket, mert szándékok (modortalan, udvarias, érdeklődő) és személyiségjegyek (kedves, utálatos) kategóriáiban gondolkodunk" (Tannen 2019: 23). 
győzésére) törekszik (vö. Habermas 1986: 175-200). A kommunikációs cselekvés itt követett értelmezése szerint olyan beszédmód, amely a beszélő és a hallgató közös megértésére irányul, és amelynek során a megértés a tudatos és a tudattalan közötti térben jön létre. A félreértés jelenségének vizsgálata stratégiai cselekvések esetében azt jelenti, hogy a befolyásolás hatására történik meg a félreértés, ahol a befolyásolás akár a félrevezetés funkcióját is betöltheti. A félremagyarázást megelözheti a félrevezetés szándéka (stratégiai cselekvés) vagy egy félreértés is, ennek megítélése az értelmezés folyamatában egy későbbi ponton történhet meg bizonyossággal, addig a megnyilatkozónak tulajdonított szándék nem tisztázott. A félrevezetés, a félremagyarázás, illetve a félreértés jelenségek tudatos megkülönböztetése azért fontos, mert könnyen belátható, hogy a hatásuk különböző értékattitűddel jár együtt a befogadó számára.

Jelen tanulmányban a vizsgálat empirikus tárgyát a különböző fogalmak öszszekapcsolásából származó félreértések alkotják, a félreértéseknek ezt a típusát elhatárolom a tisztán logikai természetủ hibáktól (a téves következtetések korábbi, szük körü értelmezése, lásd fentiekben), amelyeknek a hátterében konkrétumok (adatok) tévesztése áll (mint például a naptári napok felcserélése). Utóbbihoz hasonló tisztán logikai természetủ hibák származhatnak emlékezeti hiányosságokból, fáradtságból, figyelmetlenségből. A fogalmi alapú félreértések viszont kijelölik azt a határt, hogy meddig mehet el az ember kifejezésekhez, megnyilatkozásokhoz kapcsolódó értelmező szabadsága gyakorlásában úgy, hogy nem válik sem a saját maga, sem mások eredményes kommunikációs cselekvésének a kárára. Emellett rámutatnak arra, hogy az értelmező szabadsága nem azt jelenti, hogy bármit megtehet, hanem leginkább azt, ami az adott nyelvközösség által gyakorolt és érvényesnek tartott normák mellett megtehető. A fogalmi alapú és a logikai természetủ félreértések megvalósulását konvencionálisan egyaránt negatív tapasztalatként értékeljük, ugyanakkor lényeges különbség köztük, hogy míg az előbbinél a negatív tapasztalat feldolgozása összekapcsolódhat a közös ismeretszerzés és a kommunikációs felek kölcsönös megértésének a sikerélményével, addig az utóbbi megmarad a tévesztés egyéni felelősségének az elfogadása vagy elhárítása, illetve a hibáztatás vagy elnézés szintjén. A tanulmány bevezetőjének a végén értelmezem a fogalmi alapú félreértés jelenséget, ezután ismertetem az elméleti háttérfeltevéseim a félreértés jelenség, az intuíció és az introspekció egymáshoz való viszonyulására vonatkozóan, majd egy kognitív szemantikai keretben végzett esettanulmányban mutatom be az intuíció és az introspekció lehetséges szerepét a félreértések kialakulásában és tisztázásában, ezt követően röviden összegzem a vizsgálat eredményeit.

A fogalmi alapú félreértés jelenséget (továbbiakban: félreértés) a megértés fogalommal való viszonyában értelmezem. ${ }^{3} \mathrm{~A}$ félreértés jelensége a megértés és a meg nem értés között helyezhető el egy képzeletbeli skálán. A félreértés során a megnyilatkozó és/vagy befogadó úgy tudja, hogy adott téma kapcsán birtokában van a felek közötti közös megértéshez szükséges ismeretnek, egészében átlátja valamely tématerületet, ennek alapján a megismerés folyamatjellegét lezártnak tekinti, ebből következik,

3 A félreértés fogalom definiálása a disszertációs dolgozatom tárgyát képezi, melyhez az itt leírt fogalmi megközelítés alapul szolgál. 
hogy a megismerés folyamatjellege a tudatosság szintjén lezárul. A félreértés az egyik fél által megértett valóság elemeiből épül föl, a közös megértés folyamatában azonban egy köztes állapotot foglal el, mivel a másik fél által megértett valóságtól egy adott ponton eltávolodik, és csak az egyik fél mentális reprezentációjában valósul meg. Ennek következtében a kommunikációs felek nem jutnak közös megértésre. A félreértés feltárásának feltétele a kommunikációs cselekvés, amelyben a nyelvi tevékenységre önmonitorozás (explicit/implicit) irányul a felek közös megértésének a céljával. A félreértéssel való szembesülés a kommunikációs feleket az ismeretek újra elsajátítására kényszeríti (lásd a félreértés és az irónia egymáshoz való viszonyulását az esettanulmány végén). A félreértés kialakulásában és feltárásában - a megértés folyamatához hasonlóan - részt vesznek tudatos és (részben) tudattalan, nem szándékos tényezők is.

\section{Elméleti háttérfeltevések}

\subsection{Az intuíció jelensége - nyelvi intuíció}

A nyelvi viselkedés, tágabb értelemben a kommunikációs viselkedés, célra irányul, amelyben részt vesznek tudatos és (részben) tudattalan, nem szándékos tényezők egyaránt. Az utóbbihoz sorolható az intuíció (a nyelvi intuíció), az introspekció, valamint a beszélö-hallgató részéről egyaránt fennálló elöítéletek, továbbá az egymással szemben támasztott elvárások.

Az intuició jelenségének a leírásához annak hétköznapi, szótári meghatározásából indulok ki (lat. intueor 'megnéz'), 1. pszich 'a valóság közvetlen megértése, elözetes megfontolás v. fogalmi elemzés nélkül'; 2 . 'képesség vmely dolog egészét egyetlen megértési cselekedetben felfogni'; 3. 'ösztön, megérzés' (lásd Tolcsvai Nagy 2007: 494). Herbert Simon kognitív pszichológus intuíciómeghatározásából kitủnik a jelenségnek a mindennapi tevékenységünkben való jelenléte: „A helyzetben egy kód rejlik; a kód segítségével a szakértő megtalálja az emlékezetében tárolt információt, és ez az információ megadja a választ. Az intuíció nem több és nem kevesebb, mint felismerés" (lásd Simon 1992: 155). Németh Dezső az emlékezeti rendszerek és a nyelvi folyamatok kapcsolatának a kísérleti és neuropszichológiai vizsgálata alapján megállapítja, hogy az intuitív jelenségek hátterében egy speciális emlékezeti (tanuló) rendszer áll, ami az implicit készségtanulás. ${ }^{4} \mathrm{Az}$ implicit (= nem tudatos) készségtanulás egy elemi tanulási forma, a motoros készségek (pl. biciklizés) mellett a különbözö kognitív készségek (pl. a nyelvi, a zenei, a szociális készség), a priming (= elöfeszítés: egymással szemantikai hálózatot alkotó fogalmak kapcsolata) esetében is automatikusan és gyorsan zajlik a folyamat, ugyanakkor nincs deklaratív tudásunk róla. Németh Dezső hangsúlyozza, hogy a két rendszer (deklaratív és nem

${ }_{4}$ Memóriánk többszörös emlékezeti rendszerből áll. A deklaratív (explicit) emlékezet tartalma hozzáférhető szándékos előhívás során: a) tények szintjén, kontextus nélkül, úgynevezett szemantikus emlékezet; b) eseményekkel kapcsolatban, kontextussal együtt, úgynevezett epizodikus emlékezet. A nem deklaratív (implicit) emlékezet sajátossága, hogy a hosszú távú memóriából előhívott emlékezet a teljesítményen keresztül mutatkozik meg, és nem annak tudatos felidézésében (vö. Németh 2010). 
deklaratív emlékezeti rendszer) együttmüködik kompetitív vagy kooperatív módon a mindennapi életben, és az a jó, ha a kettőt együtt alkalmazzuk. A neuropszichológiai és az agyi képalkotó vizsgálatok azt mutatják, hogy az implicit tanulás hátterében egy meghatározott idegrendszeri struktúra, a frontális (homloklebeny) alatti basalis ganglionok és a kisagy áll, és mindkettőben kimutatható a szekvencialitás (= rejtett együttjárások, szabályszerüségek). Ez úgy kapcsolódik az intuícióhoz, hogy a környezetünkben gyakran együttjárások (a szekvenciaelemek között rejtett szabályszerüségek) vannak, és ezekre leszünk érzékenyek, és a nem tudatos felismerést követően a reakcióidő felgyorsul, így például előbb cselekszünk, mint az inger tudatosan számunkra megjelenne. Ennek alapján az intuíció által képesek vagyunk a jelenségekben (akár tudattalanul) megfigyelt szabályszerüségektől, mintázattól való eltérésnek az észlelésére és a megváltozott helyzethez való alkalmazkodásra. John Kounios és Mark Beeman szerzőpáros a „heurékaélmény” létrejöttét kutatva átlagos emberek agyi aktivitását vizsgálja, miközben például látszólag össze nem illő fogalmak közötti kapcsolatokon gondolkoznak. Németh Dezső eredményeihez hasonlóan arra a megállapításra jutnak, hogy az intuitív problémamegoldás összefügg a külvilágból tudattalanul felvett nagy ingerszámmal (sok információval), ami az agy nyugalmi állapotában (pl. nem problémamegoldás közben) történik. Ennek alapján az intuícióra jellegzetesen a komplexebb helyzetekben elvárt döntéseknél érdemes hagyatkozni. A szerzőpáros a tudatos felismerést („heurékaélmény”) megelőző sejtést azonosítja az intuícióval, amely egy olyan szellemi folyamat, amelynek során egy tudatalatti információnak az észlelése történik - egy új ötleté, megoldásé vagy perspektíváé -, és ez a folyamat addig tarthat, amíg az információ a tudatosság szintjére lép (vö. Kounios-Beeman 2015: 167). Akkor, ha az intuíció müködése nem marad ösztönszinten, hanem tudatos felismeréshez vezet, egy nem teljesen tudatos és nem teljesen tudattalan szellemi folyamat megy végbe, amelynek során az ember a mintázatokat, érzéseket összegző tapasztalatokra koncentrál inkább az analitikus gondolkodás helyett. Mivel az intuíció elősegíti az analógiák és a minták felismerését, illetve megtanulását adott helyzetekben, ezáltal a gondolatok rendszerezését támogatja, és ennek alapján a lényeglátást erösíti (vö. Kounios-Beeman 2015: 16991). Elvitathatatlan, hogy a lényeglátás szorosan kapcsolódik a megértés folyamatához, így kiemelt szerepet tölt be úgy a félreértések elkerülésében, mint egy félreértett helyzet tisztázásában.

A gondolatok és az érzelmek egymással összekapcsolódnak, és a pozitív hangulat ösztönzi a tudatalatti asszociációkat. Az intuíció mindig valamilyen hiányérzetre reagál, ugyanakkor másként érzékeljük egy problémamegoldás közben, mint egy veszélyhelyzet esetében. Előbbinél a probléma megoldásának az előzetes sejtése pozitív érzelemmel párosul, míg utóbbinál rossz érzést vált ki, hogy a dolgok valahogyan nem tủnnek összeilleszthetőnek (vö. Kounios-Beeman 2015: 177-85). Ezt az ismeretet alkalmazom a félreértések vizsgálatában. A sikeres kommunikációnak feltétele a félreértések elkerülése, ilyen értelemben a félreértés valószínüsége és a félreértés állapota veszélyhelyzetnek (negatív érzés) feleltethetők meg, míg a félreértés tisztázása a probléma megoldásának (pozitív érzés). Az intuíció szükségszerüvé teszi az emberi elme bizonyos szintủ tudattalan müködését, a tudatos mellett, amennyiben ezáltal 
válik lehetővé, hogy az a korábbiakhoz képest új eredményre jusson. Mivel a (részben) tudattalan folyamatok többnyire rejtve maradnak a(z) (ön)reflexív megfigyelö előtt, ezért az intuíció müködése egy folyamat kiteljesedésében valószínűsíthető, de nem jelenthetö ki bizonyosan.

A nyelvészetben az intuíció fogalmát a generatív grammatika tette központi eszközzé a nyelv megismerési folyamatában. Ez a szemlélet a nyelvész és a nyelvhasználó nyelvi intuícióját alapvetően azonosnak tekinti (a generatív elmélet alapján absztrakt és univerzális szabályrendszerek müködésének a felderítésére az átlag nyelvhasználó intuíciója is alkalmas), és a nyelvhasználó intuíciójának az eltérését a nyelvész által leírt nyelvtantól nem nyelvi tényezőkre vezeti vissza (pl. emlékezeti korlátok). A generatív nyelvészet keretében a nyelvhasználó nyelvi intuíciójának vizsgálata lényegileg a beszélő kikérdezését jelenti arról, hogy az adott mondatot grammatikailag helyesnek tartja-e (lásd Chomsky 1965: 19-20). Ez fölveti az intuíció-introspekció viszonyával kapcsolatos értelmezési problémát (lásd Labov 1979: 373-4; Bánfi-Bodor-Pléh 1987: 21), nevezetesen a két fogalom megkülönböztetésének a hiányát.

A szociolingvisztikai kutatások nemcsak arra mutatnak rá, hogy a nyelvi intuíció a beszélők különbözö csoportjaira vonatkozóan nem homogén, hanem a szociolingvisztikai elemzések számára támpontot ad a nyelvtani helyesség és az elfogadhatóság eltérése az egyes beszédváltozatok közötti szabályszerüségek feltárásához (vö. Kiss 1999). Kognitív pszichológiai vizsgálatok alapján a nyelvi intuíció „a beszélő tényleges állapotainak is függvénye” (lásd Bánfi-Bodor-Pléh 1987: 27), a nyelvhasználó pillanatnyi állapotai (mentális, fizikai, érzelmi) befolyásolják a nyelvi intuíció aktivitását (az aktivitás mértékét) adott nyelvi tevékenységben. Ezen felül az olyan kísérleti helyzetekben, ahol a(z) (ön)reflexiót felerösítik (pl. tükör által indukált reflexió), a nyelvhasználók a nyelvi norma szerinti formát hívják elö a nyelvhasználatban (lásd uo). A kognitív nyelvészet a generatív nyelvészettől gyökeresen eltérő álláspontot képvisel az intuíció fogalmával kapcsolatban. Az intuíció - az Osiris Nyelvtan funkcionális kognitív szemléletében (lásd Tolcsvai Nagy 2017: 51-71) - természetes velejárója a nyelvi tevékenységeknek, mivel minden nyelvi jel, minden nyelvi kifejezés szimbolikus természetü, és ez a szimbolikus jelleg a használat során alakul ki, sőt a tapasztalati alapú, gyakorlati intuitív tudás része. A tapasztalati alapú nyelvi tudást használat során alakítjuk ki, minták által sajátítjuk el és rendezzük sémákba. A nyelvhasználatban a kifejezések szimbolikus jellege és az ehhez társuló tapasztalat, amely egyéni vonatkozásban eltérő lehet, magában hordozza a félreértés lehetőségét: „A nyelvi jelnek mint egy fonológiai és egy szemantikai szerkezet szimbolikus kapcsolatának használata a pillanatnyi beszélő és a hallgató részéről nem azonos módon megy végbe. A beszélő felől valamely tapasztalat(ok) alapján történik a konstruálás, figyelmi és referenciális jelenetben" (lásd Tolcsvai Nagy 2017: 53). Az ismeretek, a tapasztalatok fogalmi megkonstruálása, valamint a megértés komplex és dinamikus folyamata a nyelvi interakcióban tudatos és (részben) tudattalan mentális műveletek (pl. absztrakció, sematizáció, kategorizáció, intuíció, introspekció) által történik. Az Osiris Nyelvtan alkalmazza az intuíció (és az introspekció) műveletét a szemantikai szerkezetek és a motivációk kutatásában, mivel a szemantikai jellemzők nem közvetlen hozzáférhetők. 


\subsection{Nyelvi intuíció - introspekció}

Az introspekció (lat. pszich 'önvizsgálat, az egyén tudatállapotának és tudati folyamatainak önmegfigyelése', lásd Tolcsvai Nagy 2007: 493) nem kevésbé vitatott fogalom a nyelvészetben, mint a nyelvi intuíció. Az introspekció természetének a megismeréséhez - kutatási témámra figyelemmel - Talmy funkcionális szemléletủ megközelítését veszem alapul. Talmy értelmezésében az introspekció a beszélővel megtörtént valamely eseménynek a felidézése, illetve nyelvi megformálása elbeszélő formában, okokozati és összefoglaló jelleggel. Hangsúlyozza, hogy az introspekció a nyelvészetben használt fö módszertan, és ezt az állitását érintő kifogásokra (pl. a megismételhetőség, a következetesség, a folyamatos hozzáférés hiánya az interakcióban stb.) funkcionális válaszokat ad (vö. Talmy 2018). A teljesség igénye nélkül itt megemlítem a nyelvészeti vizsgálati módszerek közül annak ellenörzését, hogyan történik a nyelvi tevékenység hozzáigazítása a kontextushoz, emellett a beszélő részéről a nyelvi tevékenység során folyamatosan végzett önmonitorozás müveletét. Utóbbira példaként szolgál a hétköznapi helyzetekből vett következő néhány megnyilatkozás (saját gyüjtés): „Ezt most nem értettem.” / „Nem azt mondtad, hogy ma csak későn érsz haza?” / „Nem azt mondtam, hogy nem lehet megjavítani, csak, hogy sokba fog kerülni.” Tapasztalataink alapján tudható, hogy a visszaemlékezéseken alapuló ,,igazság” könnyen meghajolhat az emocionális hatások vagy az ítéletalkotás súlya alatt. Ugyanakkor a múlt eseményeinek a folyamatos összegzése elengedhetetlen az egyén éntudata szempontjából, az introspekció szükségszerü az emberi tevékenységek megvalósulásához.

Talmy fokozati besorolást tesz azon nyelvi szempontok szerint, amelyek alapján hozzáférhetővé válik az introspekció müvelete. Ezek közül a jelen tanulmány témáját érinti, hogyan megy végbe az adott nyelvi forma jelentéséhez kapcsolt beszélői attitüdnek, a bennfoglalt jelentéseknek a kapcsolódása a kontextushoz.

Klaas Willems tanulmányában (vö. Willems 2012) megkülönbözteti többek között, hogy az intuíció fogalma általánosságban véve a filozófia tudományterületéről ered, és definíció szerint interszubjektív, míg az introspekció fogalma a pszichológia tudományterületéről származik, és szubjektív jelenség. A két fogalmat mint az elme különböző területeit írja le. Az introspekció a beszélő saját belső pszichológiai állapotainak és folyamatainak a vizsgálatára és a leírására való képesség és cselekvés. Willems az intuíciónak a megfigyeléssel való kapcsolatát hangsúlyozza, és részletes elemzésben tárja fel, hogy a beszélő nyelvi intuíciójának jogosan helye van a nyelvészeti vizsgálatokban. Ezáltal felhívja a figyelmet a korpuszalapú megközelítés szükségességére is a leíró és a módszertani kutatásokban.

A következő fejezetben egy kognitív szemantikai keretben végzett esettanulmányt mutatok be, amelyben valószínüsítem, hogy a félreértések vizsgálatában a nyelvi intuíciónak és az introspekciónak lényeges szerepe van, valamint e két jelenség egymással dinamikus kapcsolatban áll. A nyelvhasználat a kommunikációs igények kielégítését (megértés-megértetés) célozza, ennek megfelelően a nyelvi tevékenység folyamatos választások sorozata (lásd a bevezetőben Verschueren 1999), amelynek során az analógiák, a sémák felismerése, az eltérések azonosítása, valamint az összegző-következtető műveletek folyamatos elvégzése a nyelvi interakcióban 
szükségszerűvé válik. A kontextusfüggő, dinamikus jelentésképzés során a nyelvi intuíció az a mentális folyamat, amely által a nyelvi tevékenységben a sémáktól (mintáktól) való eltéréshez mint új ismerethez hozzá kívánunk férni, az introspekció az a támogató kognitív mechanizmus, ami által létrejöhet a hozzáférés.

\section{Esettanulmány - kognitív szemantikai elemzés}

Az elemzett példaszöveg egy kereskedelmi televízió reggeli élőadásában adott interjúból vett részlet (polilógus), amely az adott müsor (TV2 Mokka) müfaji keretei között a beszélt, dialogikus, tervezett szövegtípusba tartozik, egyrészt kifejtő, másrészt épít a beszédhelyzetből származó ismeretekre a résztvevők jelenlétében. Két müsorvezető irányítja a társalgást az interjúalannyal, valamennyien ismerik egymást, ezen felül az interjúban részt vevők azonos társadalmi szerepe (az interjúalany szintén müsorvezető) is befolyásolja az egymással szemben támasztott elvárásokat a diskurzus során. Az interjúnak hagyományozott szerkezete van, előre meghatározott, gondosan felépített forgatókönyv szerint készül, ez különbözteti meg többek között a kötetlen társalgástól. A diskurzus témája az interjúalany életmódváltása.

Részlet az interjúból: ${ }^{5}$

Müsorvezetők: Pachmann Péter (továbbiakban: PP.) és Szabó Dóra (továbbiakban: SZD.); interjúalany: Jáksó László (továbbiakban: JL).

1. PP: Másfél éve nincs képernyőn Jáksó László. A müsorvezető azóta kiegyensúlyozottabb életet él, hát legalábbis ezt mondja, lefogyott és többek között programozásból él. Jáksó Lászlóval beszélgetünk.

[...] [interjúfelvezetö, NM.]

2. PP: Na de tévézés lesz ebből még mondjuk ötven fölött? - mert, hogy szeptember után már ötven fölött leszel.

3. JL: Nézd, ahhoz, hogy, szóval bárki bármit mond, ahhoz, hogy az ember kapjon valami munkát, ezt ti pontosan tudjátok, ahhoz azért pattogni kell. Tehát szép gondolat az, hogy majd valaki rám telefonál, ${ }^{6}$ de ez olyasmi,

5 Az interjúrészlet saját lejegyzés, A magyar helyesírás szabályai tizenkettedik kiadása szerinti, de egy-két helyen a kiejtési jellegzetességet jeleztem a szövegben. Az interjúalany által idézett részeket idézőjelbe tettem, ezen felül a 3 . fordulóban a belső idézésben történt szereplőváltást XY-nal jelöltem. Az egyszerre beszélés nincs jelölve a 7-8. fordulóban, mert nincs szerepe az elemzésben, ugyanakkor jelöltem a 32-34. fordulóban a mondatnak a teljes megszakítását. Itt nem közöltem a teljes interjút, az interjúrészlet az elemzés szempontjából lényeges részlet, a kimaradt részekre szögletes zárójelben utaltam. Az értelmezést segítő szándékkal, dőlttel szedtem a félreértéshez közvetlen kapcsolódó megnyilatkozásokat, aláhúzással jelöltem a félreértés kiváltotta hatásmechanizmus nyelvi megnyilvánulásait, illetve a videofelvételen megfigyelt nem nyelvi jeleket rövid leírásban ismertettem (lásd szögletes zárójelben feltüntetve). Forrás (videoanyag): https://www.nlcafe.hu/tv sztarok/20180807/mas-munka-jakso-laszlo-kepernyo-nelkul-programozas-fogyas-titka/

6 A személyragos igekötők itt követett helyesírása szintén A magyar helyesirás szabályai tizenkettedik kiadása szerinti, nevezetesen az igekötővel alakilag azonos határozószók ese- 
mint a csajozás, hogy néha összetévesztik a rádiós müsorvezetöt a pszichológussal, és felhívtak tinédzserek, nagyon kedvesek, hogy hogy kell nőt hát úgy találni vagy ismerni. „Mondom: kijársz te, vagy buliba elmégy valahova? - XY: Hát nem. - Mondom: És azt várod, hogy Claudia Schiffer becsöngessen? - XY: Hát igen.” - Szóval, én mondanám, hogy igen, szívesen, de én tulajdonképpen otthon várom, hogy valaki rám rúgja az ajtót ezzel a dologgal, mert annyira már nem érdekel. Úgyhogy, de nagyon szívesen, amennyiben valaki rám nyit. ${ }^{8} \mathrm{Na}$, tudod mennyi esélye van ennek.

4. SZD: Akkor mondhatjuk, hogy a szerelem, most nincs jelen az életedben?

5. JL: Szerelem? Miért? Mondtam én ilyet?

6. SZD: Nem, csak mondtad, hogy várod, hogy valaki rád rúgja az ajtót.

7. JL: Ja, szakmailag.

8. PP: Igen, de munka-munka, munka ügyben volt.

9. JL: Ja, azt én összekevertem azzal, én mindent összekevertem mindennel.

10. PP: Na de várjál-várjál.

11. JL: Mit fecseg annyit, Laci!

12. PP: És akkor egyébként tényleg, amit a Dóri mond. Egyébként más tekintetben várod, hogy valaki rád nyissa az ajtót?

13. JL: Nem-nem.

14. PP: Vagy nem kell rád nyitni.

15. JL: Nem-nem kell rám nyitni. Tökéletes az életem.

16. SZD: De jó.

17. JL: Tökéletes az életem.

18. PP: Jól van.

19. SZD: Ezt viszont jó hallani.

20. PP: És Bencével mi a helyzet?

21. JL: Bence is.

22. PP: Mekkora már?

23. JL: Húú, 24 éves.

24. PP: Azt a! [ránéz SZD-re, visszaadva a lehetőséget, „kommunikációra hívja”, NM.] Azt a hétszázát!

25. SZD: Hogy? Gyakran beszéltek?

26. JL: Gyakran beszélünk, persze. Hát, most már, szóval a férfiaknak általában az első néhány év a probléma, ugye? - egy gyerekkel.

27. SZD: Öhöm.

tében, „csak különírt (határozószói) formája van a nem egyes szám harmadik személyü alakoknak" (2017: 57, 131.e).

7 A személyragos igekötők itt követett helyesírása szintén $A$ magyar helyesírás szabályai tizenkettedik kiadása szerinti, nevezetesen az igekötővel alakilag azonos határozószók esetében, „,csak különírt (határozószói) formája van a nem egyes szám harmadik személyü alakoknak" (2017: 57, 131.e).

8 A személyragos igekötők itt követett helyesírása szintén $A$ magyar helyesirás szabályai tizenkettedik kiadása szerinti, nevezetesen az igekötővel alakilag azonos határozószók esetében, „csak különírt (határozószói) formája van a nem egyes szám harmadik személyü alakoknak" (2017: 57, 131.e). 
28. JL: Amíg nem lehet vele beszélgetni, de aztán a többi? - semmi gond. Beszélgetünk, megdumáljuk a dolgokat, igen.

29. SZD: Ö hány éves most?

30. PP: 24. [gyorsan megválaszolja, ami rámutató jellegü SZD. figyelmetlenségére, NM.]

31. Mondom, 24! [csodálkozva, majd mindkét elemét a számnévnek elhúzva, ironikusan, NM.]

32. SZD: 24! Elnézést, még benne voltam ...

33. JL: Ez a korán kelés, ugye?

[visszautalás a hajnal 4 órai ébredés miatti panaszra, SZD. korábbi megjegyzésére még az interjú legelején, NM.]

34. SZD: ... a szerelmi témában.

35. JL: Nem-nem, persze.

36. SZD: Igen, abszolút.

37. JL: ÖÖ szóval minden rendben van teljesen, csak én összekevertem a fiatalok társkeresésével az én munkakeresésemet.

38. SZD: Igen, csak annyira úgy fogalmaztál, hogy várom, hogy ...

39. JL: És nagyon gyorsan beszélek és összevissza, és igen.

40. SZD: Igen, nehéz követni.

41. JL: Kedvesem szokta mondani, hogy „ne szakértőzz, Laci, ne szakértőzz!”

42. SZD: Igen, csak egyszerüen. Köszönöm.

43. JL: Igen.

$[\ldots][\mathrm{NM}$.

Az első forduló első mondata - Másfél éve nincs képernyőn Jáksó László -, a hallgatók tudását aktiválja napjaink egyik ismert médiaszemélyiségéről (Jáksó László, itt: szövegtopik), ehhez új ismeretként egy jól körülhatárolt időtartammal (másfél éve) pontosítja a nyilvánosság számára előhívható legközelebbi emlékeknek az idejét. A nincs képernyőn metaforikus és metonimikus kifejezés utal a médiától való távollétre. A második mondat azok számára is előhív egy ismeretet (a müsorvezető fogalma) az interjúalanyról, akik nem tudják elhelyezni a személyét mint a médiavilágnak az egyik véleményformáló alakját.

A második fordulóban elökerül a tévézés fogalma, amely kontextus nélkül 'tévét néz' jelentéssel rendelkezik, a jelen szövegkörnyezetben azonban egyértelmü jelentést hordoz, nevezetesen 'tévémüsort készít, illetve vezeti azt'. Ugyan kétszer is elhangzik ebben a fordulóban az interjúalany életkora (ötven fölött), mégis összességében háttérbe kerül az interjú további részében. Az előtérben maradó szövegtopik az interjú során a tévézés, amelyet következetesen a munka fönévvel nevesítenek a diskurzus résztvevői (lásd még 3., 8., 37. forduló), ezáltal mindannyiunk számára előhívható fogalmat, könnyen hozzáférhető sémát - tudáskeretet és a munkavégzéshez kapcsolódó forgatókönyvet, általános eseményszerkezettel - aktiválnak (a hozzáférhetőség fogalmához, lásd még Chafe 1994).

A harmadik forduló első mondata egy többszörösen összetett mondat, amelyben a nézd megszólítás és a $t i$ személyes névmás a beszédhelyzetből már ismert bizalmas 
viszonyra utalnak, illetve ezt erősítik meg, és a szövegvilág nézőpontszerkezetében a beszélő (JL.) „én, itt, most” helyzetéhez közeli viszonyt (egyes szám és többes szám második személy) jelölik. Az ember kapjon valami munkát tagmondatban, a valami munkát kifejezés elsődleges jelentése 'bármilyen munka', itt azonban nem teljesen általános értelmü, mivel a tévézésre vonatkozik.

A munka fönév séma szerinti jelentése tehát hozzá van igazítva a kontextushoz. Az ember fönévnek általános és konkrét jelentése is van, ebben a kontextusban viszont le van horgonyozva, az interjúalanyra vonatkozik, aki valós időben részt vesz a beszélgetésben.

A pattog kifejezés elsődleges jelentése passzív értelmű (pl. pattog a labda, a füle stb.), hangutánzó jelleggel, jelen kontextusban viszont a humán értelemre irányul, aktív jelentésü, hangulatfestő jelleggel (pl. Miért pattogsz már megint?), nevezetesen folyamatos, aktív cselekvéssort jelent, 'tenni kell azért, hogy valaki munkát kapjon'. A tagmondatok sorában szemantikai egységet alkot a következő célhatározói alárendelö összetett mondat: ahhoz, hogy az ember kapjon valami munkát (mellékmondat), [...] ahhoz azért pattogni kell (fömondat). Ezt az egységet szakítja meg a következö beékelt tagmondat: ezt ti pontosan tudjátok, amely a tudatosság szubjektumát az interjút vezető két műsorvezetőben (és az interjúalanyban, aki az aktuális beszélö, JL.) megosztva jelöli meg. A mondatban a referenciális középpont, vagyis a beszélő látszólag általánosítóan van megjelölve (az ember), ám az interjúalanyra vonatkozik (lásd fentiekben), vagyis a nézőpontszerkezetben történt változást a kontextus teszi hozzáférhetővé a diskurzus résztvevői és a müsort hallgatók számára. Az ezt mutató névmás kataforikus utalás, a munka főnéven keresztül utal a főnév által referált dologra.

$\mathrm{Az}$ interjúalany több esetben is témát vált a harmadik forduló második többszörösen összetett mondatában. Elöször a de ez olyasmi, mint a csajozás mellérendelö tagmondatban lép ki részben a munka(vállalás) referenciális jelenetéből a szövegvilágban, amit az interjúalany (itt: beszélö, JL.) részéről erős célt, szándékot, emellett irányultságot kifejező személyraggal jelölt határozós állandósult kapcsolattal (rám telefonál) helyez ellentétes viszonyba (lásd a de kötőszó használata). Erre a szemantikai ellentétre adható magyarázatot vezeti be a hasonlat (mint a csajozás). A hasonlítás tárgya (ez olyasmi) egy névmási anaforikus utalás a szövegbeli korábbi említésre (szép gondolat), amelyet az alárendelö összetett mondat mellékmondata dolgoz ki (majd valaki rám telefonál), és amely viszont 'a passzív várakozás mellett megvalósuló munkaajánlat' jelentéstartalmat (itt: típusjelentés) hordozza a kontextusban. Az interjúalany szintén a második mondatban újabb témaváltást visz véghez, amenynyiben a müsorvezető és a tinédzserek kettőssége a szövegvilágban színre kerül: a csajozás fogalmát az alárendelö összetett mondatban annak mellékmondata dolgozza ki (néha összetévesztik a rádiós müsorvezetőt a pszichológussal) mellérendelö kapcsolatos viszonyban egy másik szövegtani egységgel, így tömböt alkotva a szövegen belül (és felhivtak tinédzserek, nagyon kedvesek, hogy hogy kell nöt hát úgy találni vagy ismerni).

A témaváltások nézőpontváltással, időváltással és térváltással együtt valósulnak meg (lásd 3. forduló). Az első, részleges témaváltás során a referenciális középpont, 
tehát a beszélő (JL.) nincsen nyelvi kifejezésekkel jelölve, az esemény- és időszerkezet (néha összetévesztik) a csajozásra mint központi entitásra irányul, ezt a fogalmat aktiválja a hosszú távú emlékezetből. A második, teljes témaváltáskor (a müsorvezető és a tinédzserek kettőssége) a beszélő (JL.) egyértelmüen azonossá válik a rádiós müsorvezetővel (és felhivtak tinédzserek), aki egy belső idézéssel kitéröt tesz a szöveg lineáris eseményszerkezetében, egy történet elmesélésébe kezd bele (lásd harmadik fordulóban, idézőjelben közölve), kilépve ezáltal az interjú előzetesen felépített struktúrájából és (ismételten) a szövegtopikból (munka). A történet elbeszélő jellegét erősítik az olyan diskurzusjelölők, mint mondom, hát igen, hát nem, na, szóval. A mondom diskurzusjelölő elöre mutat, felvezeti az üzenetet. A hát igen / nem kifejezések a megnyilatkozás igazságtartalmának kinyilvánítására adott válaszok, amelyek a jóváhagyással vagy a kételkedéssel azt jelzik, hogy a beszélő (JL.) a saját nézőpontszerkezetéből reprezentálja a valóságot. Ezt a jelentéstartalmat erősíti a hát szubjektivizált funkciója, jelen kontextusban a beszélői attitüd (XY.) bizonytalanságot jelöl. A na diskurzusjelölő a diskurzus adott részlete és a beszélő (JL.) közti viszonyt jelöli, ugyanis nyomatékosító, érzelemkifejező funkciója van, fokozó szerepet tölt be a mondatban, a beszélő attitüdje (JL.) itt kétkedést fejez ki. Az interjúalany nyelvi tevékenységét nagyfokú metapragmatikai tudatosság (lásd Verschueren 1999: 187-98; valamint Tátrai 2006: 617-21; 2017: 1045-58) jellemzi, amelynek nyelvi kifejezői a diskurzusjelölők (hát, na, szóval) és a hallgatók befogadói tevékenységére történő utalások második személyü kognitív igékkel (nézd, tudjátok, tudod), valamint a továbbiakban az irónia (vö. Tátrai 2017: 1053-7) és az önirónia alkalmazása.

Pragmatikai keretben a belső idézés fő szervező elve az irónia (pl. kijársz te; azt várod, hogy Claudia Schiffer becsöngessen?), amelynek kapcsán az iróniát erősíti, hogy egy szemantikai ellentét feszül a tinédzsereknek a társkeresés területén megmutatkozó passzív jelenléte és ugyanakkor a jelentős sikerélmény elvárása között. Emellett az irónia túlzásba fordul át a világhírủ modellről való tudáskeret előhívásakor, amelyet az interjúalany egy szinten említ a tinédzserek ismerkedésének az általános eseményszerkezetével. Az ironikus hangvételt előkészíti a megelőző tagmondat (hogy kell nöt hát úgy találni vagy ismerni), ennek következtében a hallgatók mintegy elvárják az irónia fokozását a történet további részében. A bekezdésbe beágyazott belső idézést a szóval diskurzusjelölö - amely a kontextusban sorrendi egymásra következtetést jelent - vezeti át ismét a szövegtopikhoz (munka). Emellett a bekezdés koreferenciaszerkezetéhez járul többek között az ezzel a dologgal ragos névmás és ragos főnév kapcsolat, amelyben a névmási anaforikus utalás, a szövegbeli antecendensre és ezáltal az antecendens referensére utal, ugyanakkor szövegen belüli, közelre mutató deixis és általános a jelentése, így vonatkozhat a munkára és a csajozásra is. Hasonló szerepet tölt be a bekezdést záró ennek deiktikus elem is, amely a rám nyit kifejezésre utal. Mivel a referenciális távolság megnő a szövegtopik és a ráutaló elemek között, valamint az anaforikus utalások általános értelmủek, a topikfolytonosság meglazul, és ez támogató környezetet biztosít a félreértés létrejöttének.

Fentiek alapján a harmadik fordulóban lejegyzett megnyilatkozás magában hordozza azokat a nyelv(használat)i ismertetőjegyeket, amelyek alapján valószínüsít- 
hető, hogy a félreértés során az introspekció nem ment végbe maradéktalanul, amit a negyedik forduló megerősít.

Amellett, hogy a nyelvi intuíció elősegíti az analógiák megtalálását, a sémáktól (mintáktól) való eltérések felismerését, így az értelmezést a második fejezetben ismertetett módon, ez a folyamat szoros összefüggést feltételez az introspekció összegző-következtető jellegével, amely a félreértés elkerülését jelen esetben nem támogatja. A félreértés megvalósult az otthon várom, hogy valaki rám rúgja az ajtót ezzel a dologgal alárendelő összetett mondat vonatkozásában (lásd 3. forduló), amit az 5-6. kérdés-felelet típusú fordulópár egyértelmüen explicitté tesz.

Feltételezve, hogy az interjúban az eddigieken felül további tényezők együttállása is szerepet játszik a félreértés kialakulásában, a következökben abból indulok ki, hogy a sémák alapján csak valószínüsíteni lehet a szöveg megértési feltételeit, ${ }^{9}$ ezért mindenekelött a félreértett összetett mondatban (otthon várom, hogy valaki rám rúgja az ajtót ezzel a dologgal) az ige jelentésének a belső szerkezetét vizsgálom meg.

Az ige jelentésszerkezetének résztvevői: vki rárúg vmit vkire.

A rá igekötő elsődleges jelentése: egy entitás (elsődleges figura, trajektor) irányulását jelzi térben felülről lefelé haladva, közeledő jelleggel egy mentális ösvényen. A kezdő pillanatnyi állapotban távol van egy meghatározott térbeli entitástól (másodlagos figura, első landmark), az ösvény végén érintkezik a meghatározott térbeli entitással úgy, hogy az összes köztes pillanatnyi állapot egyetlen szerkezetben kumulatív módon jelen van. A referenciakeretben a viszonyítási pont, amelyhez képest a mentális ösvény leképeződik, elsődlegesen az emberi test.

A rá igekötő nem tartozik a legrégebbi magyar igekötők közé (meg, be, ki, le, fel, el), az ómagyar kor végén és a középmagyar korban kezdett grammatikalizálódni névutóból (rëá), de máig nem vált teljesen funkcióelemmé (vö. Hegedüs 2016). Szintaktikai sajátossága, hogy többnyire alakilag egyező határozóragos kifejezéssel együtt jelenik meg (pl. rálép a lábára), innen ered az úgynevezett „kettőző” igekötő elnevezése is. Mozgásigék mellett célra irányuló mozgást eredményez. Az elemzett példában az irányulás folyamata célzottan a személyraggal jelölt személyre vonatkozik. ${ }^{10} \mathrm{~A}$ tanulmány témája szempontjából releváns itt megemlíteni Szilágyi

9 „A nyelvi interakcióról és a beszédhelyzetről való tudás mintákban (sémákban) rendeződik el. Ezek a minták részben egyetemesek, részben kultúrspecifikusak. A nyelvi interakció és a beszédhelyzet mintái a szöveg jól leírható közegét adják. Ugyanakkor e minták alapján inkább valószínűsíthető, mint megjósolható egy bekövetkező szöveg jellege és megértési feltételei" (lásd Tolcsvai Nagy 2006: 150).

${ }^{10}$ A személyragos igekötők (ill. névmási határozószók) helyesírása, valamint az annak hátterében álló leíró nyelvészeti megközelítések (ideértve a különböző fogalmi elnevezéseket) vonatkozásában megoszlik a nyelvészek véleménye (vö. D. Mátai 1999; Kövendi 2000 Elekfi 2001; Keszler 2003; Hegedüs 2016; Szilágyi N. 2014; stb). A személyragos igekötők itt követett helyesírásához A magyar helyesírás szabályai kötetben foglaltakat tekintem irányadónak, nevezetesen az igekötővel alakilag azonos határozószók esetében, „csak különírt (határozószói) formája van a nem egyes szám harmadik személyű alakoknak" (lásd 2017: 57, 131.e). 
N. Sándornak a személyragos igekötők sokat vitatott helyesírása kapcsán tett megállapítását, miszerint: „A nyelvhasználók intuíciója azonban ettől [itt értsd: a helyesírási szabályok alapját képező nyelvtanok, N. M.] jelentősen eltér, hiszen annak ellenére többségében egybeírják az ilyen szerkezeteket, hogy a szabályok éppen az ellenkezőjét írják elő" (lásd Szilágyi N. 2014, in: Benő-Fazekas-Zsemlyei 2015: 15-24).

A rárúg ige jelentésszerkezetében a három résztvevő közül (valaki: elsődleges figura, valamit: másodlagos figura, valakire: másodlagos figura), a figyelem a humán cselekvőre irányul, ez a feltünőbb. Tranzitív, cselekvő ige, pejoratív értelmủ szó, beszélt nyelvi stílus (társalgási), bizalmas stílusárnyalattal.

A rúg ige szótári jelentése (ÉrtSz. V. kötet, 1980), ${ }^{11}$ a teljesség igénye nélkül:

1. élőlény (ember, állat) lábával, lábfejének valamely részével hirtelen, durván üt, taszít, lök valamit;

2. valamit ily módon elér vagy létrehoz (pl. gólt rúg);

3. ezt a mozdulatot valahova irányítja vagy valakin végzi (pl. belerúg, odarúg).

4. átvitt értelemben: a) valaki durván támad, sért, bánt valakit (pl. Kritikus megjegyzésével kíméletlenül belerúgott.); gépi szerkezet hirtelen erősen elmozdul, és ezzel meglöki az embert (pl. A pisztoly rúgott).

A fenti gondolatmenetet folytatva, a rárúgja az ajtót állandósult kapcsolat típusjelentésének az eseményszerkezete: egy entitás betör egy másik entitás szférájába, és ennek a helyébe lép ténylegesen (lezárul a folyamat), illetve valószínüsíthető, hogy ez rövid időn belül megtörténik (a folyamat még tart), például: $A$ Youtube tényleg rárúgja az ajtót a streaming piacra ${ }^{12}$ ('verhetetlen, elsöprő ajánlatot tesz komoly szándékkal').

1. a folyamat váratlanul történik, többnyire helyzet-, vagy állapotváltozás kíséri, tehát jelentős erőkifejtéssel jár együtt: a kezdeményező entitás aktivitását a fogadó entitás elszenvedi.

Megvizsgálva a rárúg ige belső szerkezetét, valamint a rárúgja az ajtót állandósult kapcsolat típusjelentésének az eseményszerkezetét, a félreértés leírható a kontextusban szereplö rám rúgja az ajtót személyraggal jelölt határozós állandósult kapcsolat típusjelentése alapján, nevezetesen: a munkanélküliség passzív állapotának a helyébe lép a munkavállalás aktív állapota, egy váratlan és célzott ajánlaton keresztül; ehhez képest a műsorvezető (SZD.) reprezentációjában megvalósult jelentés a kontextus dinamiká-

${ }^{11}$ Itt megjegyzem, hogy A magyar nyelv értelmezö szótára a rúg igének az igekötős alakváltozatai között a következő igekötőket, illetve igekötő funkciót betöltő nyelvi elemeket ismerteti: bele, neki, oda /ide, agyon, amelyek között a rá nem szerepel, valamint a Magyar értelmezö kéziszótár (2003) sem említi.

12 https://muzzak.blog.hu/2018/06/22/ezuttal_a_youtube_tenyleg_komolyan_gondolhatja_ zeneipari_terveit 
jában: az egyedüllét passzív állapotának a helyébe lép a társkapcsolat aktív állapota, a társkeresés célzott, sikeres, de (mindig) váratlan eredményeként. A rám rúgja az ajtót kifejezés típusjelentésének a kontextushoz történő hozzáigazításában több tényező is szerepet játszik. Egyrészt az interjúalany a munkanélküliség és az egyedüllét passzív állapotát is az otthonléttel társítja a 3. fordulóban (vö. otthon várom, hogy valaki rám rúgja az ajtót / kijársz te; azt várod, hogy Claudia Schiffer becsöngessen?). Másrészt az interjúalany részéröl a 3. fordulóban elhangzott rám rúgja kifejezés egy szinonim sort alkot a szintén általa említett rám telefonál és a rám nyit határozós állandósult kapcsolatokkal (lásd uo.), valamennyi szinonim kifejezése fokozati különbséggel a típusjelentésnek (lásd lentebb fokozati skála), a szinonim sor elemei azonban nem a fokozatiság sorrendjében hangzanak el, mivel a fokozati skála csúcsán lévő kifejezést (rám rúgja) az interjúalany az ironikus hangvételü második topikváltás (belső idézés) után közvetlen jeleníti meg, így a katarzis szempontjából nem válik el élesen a második topikváltás (belső idézés) jelenete a szövegtopikhoz (munka) visszatérő jelenettől. Harmadrészt a belső idézésnél alkalmazott szemantikai ellentét mint az irónia forrása (kijársz te; azt várod, hogy Claudia Schiffer becsöngessen?) ismétlödik a szövegtopikhoz visszatérö jelenet részeként (Szóval, én mondanám, hogy igen, szivesen, de / én tulajdonképpen otthon várom, hogy valaki rám rúgja az ajtót ezzel a dologgal, mert annyira már nem érdekel).

\section{FOKOZATI SKÁLA}

a cselekvés erőkifejtése, befejezettsége, emocionális hatása, valamint a lexikalizálódás folyamata alapján

rám telefonál ('felveszi a kapcsolatot', emocionális hatás: •) > rám nyit ('ajánlatot tesz', emocionális hatás: ••) > rám rúgja az ajtót ('helyébe lép vminek', emocionális hatás: •••)

A félreértés a negyedik fordulóban válik felismerhetővé a müsorvezető (SZD.) kérdésében: Akkor mondhatjuk, hogy a szerelem most nincs jelen az életedben? Az akkor diskurzusjelölő a beszélgetés irányításában itt a szó átvételét jelöli, részben összegzést vezet be, és következtető tartalma miatt oksági jelleggel visszacsatol a szöveg előzményére, részben kapcsoló jelleggel előreutal a szövegben. A müsorvezető a mondhatjuk többes szám első személyü, feltételes módú igealakkal többek között az interjúalanyt is bevonja az összegző-következtető müveletbe, nevezetesen az ige elsődleges jelentése ('kimond, megszólal') helyett a másodlagos jelentés aktiválódik ('érthetjük úgy, hogy') az interakció dinamikájában. Ugyanakkor a -hat morféma metapragmatikai jelzés, reflektálttá teszi, hogy a megnyilatkozó a tudatosság szubjektuma. A müsorvezető (SZD.) a reprezentációjában megvalósult jelentésnek az önkontrollját végzi el részint a negyedik fordulóban, amikor reflexíven, összegző-következtető jelleggel visszakérdez a tartalomra. Ez a visszakérdezés az introspekció megnyilvánulása, ami a szemantikai szerkezetek szintjén férhető hozzá. Megjegyzem: a hallgató részéről vélt vagy valós félreértések elkerülésében a visszakérdezésnek lényegi szerepe van, jelen esetben azonban az elhangzottak introspektív megismétlése a kérdő mondat- 
típus ellenére sem teszi lehetővé, hogy a félreértés ne váljon kifejezetté a hallgató számára. Pragmatikai megközelítéssel ez a helyzet többek között úgy írható le, hogy a müsorvezető arca, valamint az interjúalany arca is - utóbbi többek között a közös jelentésalkotás folyamatába való bevonása miatt (lásd „mondhatjuk”) -, fenyegetve van (vö. Goffman arcteóriája, 1967; Brown-Levinson udvariasságelmélete, 1987). Az interjúalany számára ez a fenyegetettség a félreértés megvalósulása (veszélyhelyzet, negatív érzelem), amelynek felelösségébe nyíltan bevonják, így a továbbiakban a probléma megoldásán dolgozik.

A müsorvezető (SZD.) reprezentációjában megvalósult jelentésre válaszként, az interjúalany átveszi a társalgás irányítását, és szintén kérdés formájában visszacsatol a saját szavaira (vö. 5. forduló), sőt a mondtam én ilyet? - visszakérdezéssel elvárást fogalmaz meg a müsorvezetővel szemben, aki azt a soron következő fordulóban (lásd 6.) teljesíti (Nem, csak mondtad, hogy várod, hogy valaki rád rúgja az ajtót), ezáltal az együttmüködéséről biztosítja az interjúalanyt. A ja diskurzusjelölő ismétlődő jelenléte a szövegben (vö. 7., 9. forduló) az interjúalany attitüdjét jelöli (csodálkozás), aki tisztázza a megvalósult jelentést azzal, hogy visszahelyezi a típusjelentés szintjére (szakmailag). Ezt követően visszautal az általa végrehajtott témaváltásokra (azt-azzal), amelyeket túlzó ironikus nézőpontból konstruál meg (mindent - mindennel). Az irónia és az önirónia megnyilvánulása a diskurzusban az affektív (érzelmi, motivációs) tényezők tisztázásáért tett mentális erőfeszítés (vö. 9., 11. forduló).

Az önirónia válaszreakció a müsorvezető (SZD.) és az interjúalany arcára irányuló fenyegetettségnek az elhárítására, amelynek kapcsán az interjú dinamikáját az interjúalany irányítja. Az öniróniát magas szintü (ön)reflexió jellemzi, és az introspekció által kap motivációt, ennek során az interjúalany megfigyeli a beszédhelyzetet, és összeveti a meglévő ismereteivel. Az önirónia mint nyelvi stratégia kiválasztásában és megvalósulásában valószínüsíthető a nyelvi intuíció közremüködése, amennyiben az interjúalany arra a felismerésre jut, hogy eltérés van az általa szándékolt jelentés és a müsorvezető (SZD.) részéről megvalósult jelentés között (félreértés, negatív érzelem), és müveleti szinten alkalmazkodik a megváltozott helyzethez a nyelvi stratégia megválasztásánál a szándékainak megfelelően (félreértés tisztázása, pozitív érzelem). A félreértéshez kapcsolódó affektív tényezők tisztázásában tehát az önirónia nyelvi stratégiaként funkcionál, eredményességében meghatározó többek között a begyakorlottság és a tapasztalat.

A 10-36. forduló tartalmilag és terjedelemben is szemléletesen mutatja a félreértés hatásmechanizmusát a diskurzus további részében, nevezetesen azt, hogy zavart kelt a félreértést explicitté tett müsorvezető (SZD.) kommunikációjában úgy emocionálisan, mint a kognitív müveletekben (vö. 19., 25., 29., 32., 34. forduló), és (jelentés)meghatározó lenyomatává válik a diskurzusnak. Egyúttal motivációs erővel is bír a kommunikációban részt vevő felek számára, ugyanis a másik müsorvezető (PP.) spontán témaötletet kap a félreértés nyomán (vö. 12. forduló), az interjúalany pedig abban motivált, hogy felmérje, mennyiben indokolt, esetleg szükséges a részéről (további) mentális erőfeszítéseket tenni a félreértés tisztázásához (vö. 37. forduló).

Az interjúban a félreértés tisztázásának az utolsó fázisa a 37-43. forduló, amelyekben gyakran elöfordul az igen diskurzusjelölö, amelynek jóváhagyási funkciója 
is van a magyar nyelvben (itt: nem azonos a kérdésre adott válasszal). Ezáltal a müsorvezető (SZD.) és az interjúalany is jelzi, hogy aktív résztvevője a diskurzusnak, és nemcsak figyel, de érti, amiről szó van. A 38. fordulóban megfigyelhető igen, csak kifejezés (diskurzusjelölő + árnyaló partikula) azt jelzi, hogy a beszélő új perspektívát fog bevezetni, vagyis visszaveszi a beszédjogot. Míg a többi esetben önmagában az igen diskurzusjelölő meghagyja a beszédjogot a beszélőnél, vagyis a jóváhagyást, az egyetértést jelöli.

$\mathrm{Az}$ interjúalany mentális erőfeszítését mutatja a félreértés tisztázásában, hogy nyelvileg kifejezetté teszi a félreértés létrejöttének az okait (lásd 37., 39. forduló), amelyek mindegyikét a saját megnyilatkozásához köti, majd egy nézőpontváltással és iróniát alkalmazva egy harmadik, külső nézöpontból (kedvesem szokta mondani) is megerősíti a saját felelősségét a félreértésben (lásd 41. forduló), amelyben a müsorvezetôvel (SZD.) egyetértenek (lásd 42-43. forduló).

Az esettanulmányban az irónia szerepet töltött be úgy a félreértés kialakulásában, mint a félreértés tisztázásában. A félreértés és az irónia egymáshoz való viszonyát a következökben összegzem: a félreértés esetében kialakul szemantikai szinten egyfajta törés az ismeretek összegzésében, amely nem várt módon (időben, helyen és formában) valósul meg, ebben hasonlatos az iróniával; ugyanakkor a szemantikai törés a félreértés során az értelmezésből elvesz, míg az irónia esetében a szemantikai törés egyértelmüen hozzáad az értelmezéshez. A félreértést követő megértés az eredeti üzenethez tér vissza, míg az irónia megértése az eredeti üzeneten túlmutat.

\section{4. Összegzés}

A jelen tanulmányban az intuició (nyelvi intuició) és az introspekció szerepét vizsgáltam a fogalmi alapú félreértések kialakulásában és tisztázásában egy interjúrészlet elemzésén keresztül kognitív szemantikai keretben. A bevezetőben a félreértés jelenséget a funkcionális kognitív nyelvészet elméleti keretében írtam le, és a fogalmi alapú félreértéseket elhatároltam a tisztán logikai természetű hibáktól, valamint megkülönböztettem a félrevezetés és a félremagyarázás jelenségeitől. Ismertettem az intuíció (nyelvi intuíció) és az introspekció fogalmakhoz kapcsolódó elméleti háttérfeltevéseket a kutatási téma szempontjából. Ezt követően bemutattam az esettanulmányt. A félreértés több tényezö együttállása révén jött létre az interjúrészletben, amelyek a következők: két egymást követő témaváltás, ami nézőpontváltással és tér-idő váltással járt együtt; jelentős mértékủ referenciális távolság a szövegtopik és az utalóelemek között, emellett általános értelmü anaforikus utalások, amelyek okán a topikfolytonosság meglazult. Mindezek mellett a jelentéseknek a kontextushoz való igazítása nem történt meg (a séma csak valószínüsít, az introspekció nem ment végbe maradéktalanul), valamint a típusjelentés és a megvalósult jelentés különvált, utóbbit az ige (itt: személyraggal jelölt határozós állandósult kapcsolat) szemantikai belső szerkezetének a leírásával mutattam be. Ismertettem a félreértés tisztázásáért tett mentális erőfeszítéseket, így mindenekelőtt a félreértett jelentéstartalomnak a kontextushoz való hozzáigazítását, emellett a félreértéssel együtt járó affektív tényezőknek a tisztázását. Az introspekciót azonosítottam egy összegző-következtető kérdő mondat- 
ban a szemantikai szerkezetek szintjén, valamint az öniróniával hoztam kapcsolatba a motivációs tényezők szintjén. Az interjúrészlet kontextusában valószínüsítettem a nyelvi intuició közremüködését a félreértés felismerésében, valamint a félreértés tisztázásához az önirónia alkalmazásában. A nyelvi intuícióra hoztam egy további példát - a félreértésektől elvonatkoztatva - a személyraggal jelölt határozós állandósult kapcsolatoknak a sokat vitatott helyesírásában, amelynek hátterében ezek különböző nyelvtani kategorizációja áll. A tanulmány végén összegeztem a félreértés és az irónia egymáshoz való viszonyát. A jelen tanulmányban feltárt analógiák és összefüggések további esettanulmányok készítését ösztönzik a kutatási témában.

\section{SZAKIRODALOM}

Balázs János (szerk.) 1980. A magyar nyelv ételmezö szótára. V. kötet. Akadémiai Kiadó, Budapest.

Bánfi Beáta - Bodor Péter - Pléh Csaba 1987. A megítélési helyzet hatása nyelvhelyességi ítéletekre. Magyar Nyelvör 111: 20-9.

Brown, Penelope - Levinson, Stephen 1987. Politeness. Some universals in language use. Cambridge University Press, Cambridge. https://doi.org/10.1017/CBO9780511813085

Chafe, Wallace 1994. Discourse, consciousness and time. The University of Chicago Press, Chicago, 56-210.

Chomsky, Noam 1965. Aspects of a Theory of Syntax. The MIT Press, Cambridge, MA. https://doi.org/10.21236/AD0616323

D. Mátai Mária 1999. A névmások története a középmagyar kor végéig. Magyar Nyelvör 123: $438-64$.

Elekfi László 2001. Személyragozott igekötők? Magyar Nyelvơr 125: 250-3. http://epa.oszk. $\mathrm{hu} / 00100 / 00188 / 00022 / 125212 . \mathrm{htm}$

Fiske, Susan T. - Taylor, Shelley E. 1991. Social Cognition. International Edition. McGrawHill, New York.

Goffman, Erving 1967. Interaction ritual: essays on face to face behaviour. Anchor Books, Garden City, New York.

Habermas, Jürgen 1986. Magyarázatok a kommunikatív cselekvés fogalmához. Magyar Filozófiai Szemle XXX: 175-200.

Hegedüs Veronika 2016. Egyezö igekötők a magyarban? A „kettőző” igekötők grammatikalizációja. PPT-prezentáció. Nyelvelmélet és diakrónia konferencia. http:// www.nytud.hu/oszt/elmnyelv/mgtsz/2016/031 hegedus_nyelvelmeletkonf2016_slides.pdf

Németh Dezső 2010. Az intuíció pszichológiai és idegtudományi alapjai. SZTE-konferencia. http://www.oldportal.u-szeged.hu/szabadegyetem-szeged/szemeszter/intuiciopszichologiai/intuicio-pszichologiai?objectParentFolderId=11373

Kertész András - Rákosi Csilla 2007. Adatok és körben forgó érvelés a fogalmi metaforaelméletben. In: Csatár Péter - Pethő Gergely (szerk.): Szemantikai intuiciók mint nyelvészeti adatok. Kossuth Egyetemi Kiadó, Debrecen, 95-128.

Keszler Borbála (szerk.) 2000. Magyar grammatika. Nemzeti Tankönyvkiadó, Budapest.

Kiss Jenő 1999. Nyelvi intuíció és elfogadhatósági ítéletek. Magyar Nyelv 95: 129-38.

Kounios, John - Beeman, Mark 2015. Das Aha-Erlebnis: Wie plötzliche Einsichten entstehen und wie wir sie erfolgreich nutzen. Deutsche Verlags-Anstalt, 165-215.

Kövendi Dénes 2000. A rá és személyragos alakjai mint határozószók és mint igekötők. Magyar Nyelvör 124: 270-2. http://epa.oszk.hu/00100/00188/00018/124218.htm 
Labov, William 1979. A nyelv vizsgálata társadalmi összefüggésben. In: Pléh Csaba - Terestyéni Tamás (szerk.): Beszédaktus-kommunikáció-interakció. Tömegkommunikációs Kutatóközpont, Budapest, 365-98.

Pusztai Ferenc (szerk.) 2003. Magyar értelmezö kéziszótár. Akadémiai Kiadó, Budapest.

Simon, Herbert A. 1992. What is an ,explanation” of behavior? Psychological Science 3/3: 150-61. https://doi.org/10.1111/j.1467-9280.1992.tb00017.x

Szilágyi N. Sándor 2014. Nyelvészek felelőssége. In: Benő Attila - Fazekas Emese - Zsemlyei Borbála (szerk.): Többnyelvüség és kommunikáció Kelet-Közép-Európában. A MANYE kongresszusok előadásai 11. Erdélyi Múzeum Egyesület, Kolozsvár, 15-24.

Talmy, Leonard 2018. Introspection as a Methodology in Linguistics. In: Ten Lectures on Cognitive Semantics. Distinguished Lectures in Cognitive Linguistics 4. https://doi. org/10.1163/9789004349575

Tannen, Deborah 2019. Miért értjük félre egymást? Tinta Könyvkiadó, Budapest.

Tátrai Szilárd 2006. „Várj csak, hogy is kezdjem, hogy magyarázzam?” - Néhány megjegyzés a metapragmatikai tudatosság jelöléséről. In: Mártonfi Attila - Papp Kornélia - Slíz Mariann (szerk.): 101 írás Pusztai Ferenc tiszteletére. Argumentum, Budapest, 617-21.

Tátrai Szilárd 2017. Pragmatika. In: Tolcsvai Nagy Gábor (szerk.): Nyelvtan. A magyar nyelv kézikönyvtára 4. Osiris Kiadó, Budapest, 899-1058.

Terestyéni Tamás 2014. Tudatos és szándékolt versus tudattalan és nem szándékolt az emberi kommunikációban. In: Bagdy Emőke - Grezsa Ferenc - Komlósi Piroska - Sepsi Enikő - Spannraft Marcellina (szerk.): Ki látott engem? Buda Béla 75. Károli Gáspár Református Egyetem, L'Harmattan Kiadó, Budapest, 85-103.

Tolcsvai Nagy Gábor 1998. A nyelvi norma. Nyelvtudományi Értekezések 144. Akadémiai Kiadó, Budapest.

Tolcsvai Nagy Gábor 2006. Szöveg és szövegtan. In: Kiefer Ferenc (szerk.): A magyar nyelv. Akadémiai Kiadó, Budapest, 149-174.

Tolcsvai Nagy Gábor (szerk.) 2007. Idegen szavak szótára. A magyar nyelv kézikönyvtára 2. Osiris Kiadó, Budapest.

Tolcsvai Nagy Gábor 2017. Bevezetés. In: Tolcsvai Nagy Gábor (szerk.): Nyelvtan. A magyar nyelv kézikönyvtára 4. Osiris Kiadó, Budapest, 51-71.

Tomasello, Michael 2002. Gondolkodás és kultúra. Osiris Kiadó, Budapest.

Tóth Etelka (szerk.) 2017. Magyar helyesirási szótár. A magyar helyesírás szabályai tizenkettedik kiadása szerint. Akadémiai Kiadó, Budapest.

Verschueren, Jef 1999. Understanding Pragmatics. Arnold, London, New York, Sydney, Auckland.

Willems, Klaas 2012. Intuition, introspection and observation in linguistic inquiry. Language Sciences 34: 665-81. https://doi.org/10.1016/j.langsci.2012.04.008

\section{Nagy Marianna \\ doktorandusz}

ELTE, Nyelvtudományi Doktori Iskola

https://orcid.org/0000-0002-5785-0757 


\section{SUMMARY}

Nagy, Marianna

\section{A conceptual approach to misunderstandings and the role of intuition and introspection in their study}

The present paper forms part of a cognitive semantic study exploring misunderstandings in Hungarian discourses. Research on misunderstandings can be traced back to the tradition of Aristotelian logic, on the basis of which they have been treated as instances of false inference in the literature. At the same time, scholars now seem to agree that false inferences result from both semantic and pragmatic factors. However, in this theoretical approach, misunderstanding has not yet been systematically distinguished from misleading and purposeful misinterpretation, with the difference between conceptual misunderstanding and purely logical mistakes also awaiting clarification. The introductory part of the paper offers an interpretation of misunderstanding along these lines in a cognitive semantic framework, and spells out the study's theoretical background assumptions. This is followed by a case study which assigns a key role to linguistic intuition and introspection in both the emergence and elimination of misunderstanding.

Keywords: cognitive semantics, misunderstanding, conceptual approach, misleading, misinterpretation, intuition and introspection, case study.

\section{Verbális és vizuális alakzatok a 2019-es Super Bowl reklámjaiban}

\section{Bevezetés}

A humor reklámokban betöltött szerepének vizsgálata nem új keletü, de máig népszerü téma. Kutatásom relevanciáját ez esetben maga az esemény adja, amelyhez a reklámozás kapcsolódik. A sport mára az egyik legjövedelmezőbb iparággá, legtöbbet reklámozott termékké, valamint a legfőbb reklámozási területté is vált: emberek milliói kíváncsiak ugyanis a különböző sporteseményekre vagy azok közvetítésére. Mindez hatalmas fogyasztói kiadást jelent, nem véletlen tehát, hogy fontos lett egyrészt a fogyasztók figyelmét ezekre az eseményekre irányítani, másrészt pedig a nevesebb nagyvállalatok is óriási összegeket költenek arra, hogy egy-egy sportrendezvényen megjelenhessen a nevük, a termékük. Írásomban a 2019-es Super Bowl döntőjét népszerüsítő reklámokban vizsgálom a humoros nyelvi és képi megoldásokat. Célom annak feltárása, hogy a vizsgált reklámokban a verbális és vizuális alakzatok miként járulnak hozzá a humoros hatás eléréséhez.

Vizsgálatom interdiszciplinárisnak tekinthető, elméleti keretét egyrészt a kommunikációtudomány, a reklámkommunikációra vonatkozó korábbi vizsgálatok, másrészt pedig az alakzatok retorikai, pragmatikai vizsgálatai adják. Az elemzés a sport és a reklám kapcsolatának bemutatásával indul (2), majd az alakzatok fogalmának tisztázása után kitér ezek reklámokban betöltött szerepének a bemutatására (3). Ismerteti 